Original Article

\title{
Antiproliferative, genotoxic and mutagenic potential of synthetic chocolate food flavoring
}

\author{
Potencial antiproliferativo, genotóxico e mutagênico do aroma de chocolate sintético \\ para alimentos
}

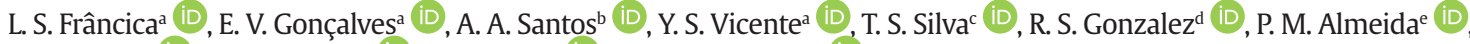
L. L. Feitozac (iD) P. A. A. Buenof (iD, D. C. Souza ${ }^{\mathrm{f}}$ iD and A. P. Peron f,g,h* (iD

a Universidade Tecnológica Federal do Paraná - UTFPR, Curso de Engenharia Ambiental, Campus de Campo Mourão, Campo Mourão, PR, Brasil

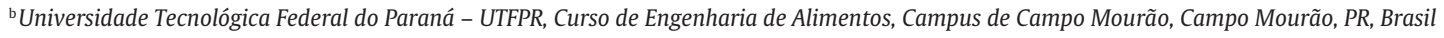
c Universidade Federal do Piauí - UFPI, Programa de Pós-graduação em Genética e Melhoramento - PPGM, Campus Ministro Petrônio Portella CMPP, Teresina, PI, Brasil

¿Universidade Tecnológica Federal do Paraná - UTFPR, Departamento de Química - DAQUI, Campus de Campo Mourão, Campo Mourão, PR, Brasil e Universidade Estadual do Piauí - UESPI, Faculdade de Ciências Médicas - FACIME, Campus Poeta Torquato Neto, Teresina, PI, Brasil

${ }^{\mathrm{f}}$ Universidade Tecnológica Federal do Paraná - UTFPR, Departamento de Biodiversidade e Conservação da Natureza - DABIC, Campus de Campo Mourão, Campo Mourão, PR, Brasil
\end{abstract}

g Universidade Tecnológica Federal do Paraná - UTFPR, Programa de Pós-graduação em Inovações Tecnológicas - PPGIT, Campus de Campo Mourão, Campo Mourão, PR, Brasil

hUniversidade Tecnológica Federal do Paraná - UTFPR, Programa de Pós-graduação em Engenharia Ambiental - PPGEA, Campus de Francisco Beltrão, Francisco Beltrão, PR, Brasil

\begin{abstract}
Flavoring additives are of great technological importance for the food industry. However, there is little information regarding the toxicological properties of these micro-ingredients, especially at the cellular level. The present study used meristematic root cells of Allium cepa L. to evaluate the toxicity of a liquid, aroma and flavor synthetic chocolate additive, manufactured and widely marketed throughout Brazil and exported to other countries in South America. The flavoring concentrations evaluated were $100.00 ; 50.00 ; 25.00 ; 1.00 ; 0.50$ and $0.25 \mu \mathrm{L} / \mathrm{L}$, where the highest concentration established was one-hundred times lower than that commercially suggested for use. The concentration $100 \mu \mathrm{L} / \mathrm{L}$ substantially reduced cell division of meristems within 24- and 48-hours exposure. Concentrations from 100.00 to $0.50 \mu \mathrm{L} / \mathrm{L}$ resulted in a significant number of prophases to the detriment of the other phases of cell division, indicating an aneugenic activity, and induced a significant number of cellular changes, with emphasis on micronuclei, nuclear buds and chromosomal breaks. Under the established analysis conditions, with the exception of concentration $0.25 \mu \mathrm{L} / \mathrm{L}$, the flavoring of chocolate caused cytotoxicity, genotoxicity and mutagenicity to root meristems.
\end{abstract}

Keywords: aroma and flavor additive, cytotoxicity, aneugenic potential, cellular changes, meristematic tissue.

\begin{abstract}
Resumo
Os aditivos aromatizantes têm grande importância tecnológica para a indústria de alimentos. Contudo, poucas são as informações quanto as propriedades toxicológicas desses microingredientes, especialmente, em nível celular. No presente estudo avaliou-se, sobre as células meristemáticas de raízes de Allium cepa L., a toxicidade de um aditivo sintético líquido de aroma e sabor de chocolate, fabricado e amplamente comercializado em todo Brasil, e exportado para outros países da América do Sul. As concentrações de aromatizante avaliadas foram 100,00; 50,00; 25,00; 1,$00 ; 0,50$ e $0,25 \mu \mathrm{L} / \mathrm{L}$, onde a maior concentração estabelecida foi cem vezes menor que a sugerida comercialmente para uso. Com base na interpretação dos resultados, a concentração $100 \mu \mathrm{L} / \mathrm{L}$ reduziu substancialmente a divisão celular dos meristemas nas 24 e 48 horas de exposição. As concentrações 100,00 a 0,50 $\mu \mathrm{L} / \mathrm{L}$ demonstraram número significativo de prófases em detrimento as outras fases da divisão celular, indicando ação aneugênica, e induziram número significativo de alterações celulares, com ênfase a micronúcleos, broto nucleares e quebras cromossômicas. Nas condições de análises estabelecidas, com exceção a concentração $0,25 \mu \mathrm{L} / \mathrm{L}$, o aromatizante de chocolate causou citotoxicidade, genotoxicidade e mutagenicidade aos meristemas radiculares.
\end{abstract}

Palavras-chave: aroma e aditivo de sabor, citotoxicidade, potencial aneugênico, alterações celulares, tecido meristemático.

*e-mail: anaperon@utfpr.edu.br

Received: September 16, 2020 - Accepted: October 5, 2020

This is an Open Access article distributed under the terms of the Creative Commons Attribution License, which permits unrestricted use, distribution, and reproduction in any medium, provided the original work is properly cited. 


\section{Introduction}

Aroma and flavor additives are essential for the industry due to the low cost, the sensory functions provided and the time in industrialized and semi-industrialized foods (Santos et al., 2020). They have a complex formulation consisting of solvents, diluents, preservatives, dyes, sweeteners, flavor enhancers and food acids, and are classified in the industry into natural and synthetic (Brasil, 2007; Sales et al., 2018). Internationally, the rules of use for flavoring microingredients are set by the food safety agencies Food and Agriculture Organization (FAO) and Flavor and Extract Manufacturers Association (FEMA) (Sales et al., 2018), and nationally by the Health Surveillance Agency (ANVISA), through Resolution RDC 2, of January 15, 2007 (Brasil, 2007).

Scientific studies have shown that aroma and flavor micro-ingredients, when ingested in large amounts and/or for a long period, can be harmful to the digestive system and cause irritation and narcotic effects in mammals (Ramesh and Muthuraman, 2018). However, food safety agencies report a lack of information on the potential cytotoxic, genotoxic and mutagenic properties of these additives (Sales et al., 2018). The evaluation of such parameters is important for guiding the construction and/or modification of established norms for the use/intake of food additives and for the determination of the Daily Intake Index (IDA) for microingredients (Brasil, 2007; Santos et al., 2020). Furthermore, it is necessary to establish toxicity at the cellular level of the different classes of food additives, due to the knowledge that some types of cancer are due to the interaction between endogenous and environmental factors, the most notable of which is the diet, especially when containing many processed foods (Koca et al., 2015).

In Brazil, synthetic food flavorings are found in variety stores and supermarkets, however, they are sold without quantity limits, at a very affordable cost, and without inspection of the actual concentrations used in processed foods (Silva et al., 2017; Sales et al., 2018, Santos et al., 2020). Among the food flavorings are the liquid, aroma and flavor synthetic chocolate additives, which in this country, in addition to industry, are widely used in small food factories, bakeries and confectioneries, in the production of sweet foods of the most varied types, being widely consumed by children and adults.

According to the literature, the chemical composition of liquid chocolate flavorings, in general, consists of ethyl alcohol (solvent); ethyl vanilla (flavoring); xanthan gum (homogenizer); benzoic acid and diacetyl 2,3 - butadione (diluents); potassium benzoate and potassium sorbate (preservatives); monopotassium glutamate and magnesium diglutamate (flavorings); corn syrup (sweetener); citric acid and tartaric acid (food acids) and caramel IV (dye)(Brasil, 2007). Variation among brands/manufacturers of flavorings of chocolate is mainly due to the concentration of ethyl vanilla that, together with monopotassium glutamate and magnesium diglutamate ingredients in the composition, characterizes the chocolate flavor of the food (Sherwood and Boitano, 2016).

However, there are studies reporting that chemical compounds present in chocolate additives caused toxicity at the cellular level in different bioassays (Whittaker et al., 2008; Demir et al., 2011; More et al., 2012;
Silva et al., 2017; Sales et al., 2018). Thus, it becomes relevant to evaluate commercialized chocolate flavoring solutions to check their cytotoxic, genotoxic and mutagenic potential.

Root meristem of Allium cepa L. (onion) is an efficient test system for the evaluation of cytotoxicity, genotoxicity and mutagenicity of chemical substances and compounds, since the resulting data show satisfactory similarity to results observed in animal and cell culture bioassays (Tabrez and Ahmad, 2011; Herrero et al., 2012). It is a test with excellent kinetic properties of cell proliferation, large and few chromosomes $(2 \mathrm{n}=16)$, which facilitates the detection of chromosomal aberrations and mitotic spindle abnormalities (Herrero et al., 2012; Mendes et al., 2020). Also allows the verification of changes in cell division or mitotic index when exposed to chemical compounds with potential cytotoxic activity (Caritá and Marin-Morales, 2008; Silva et al., 2020). A. cepa system has been used by different researchers in the assessment of food additives, such as food colorings, flavorings and preservatives (Türko lu, 2007, Marques et al., 2015; Rocha et al., 2018; Sales et al., 2017, 2018).

Therefore, the present study aimed to evaluate the cytotoxicity, genotoxicity and mutagenicity of a liquid food flavoring of chocolate manufactured and sales leader in Brazil, also exported to other South American countries, in root meristem cells of $A$. cepa testing different concentrations and exposure times.

\section{Material and methods}

Obtaining flavoring, chemical composition on the label and determination of treatments for toxicity

The aroma and flavor additive of chocolate, liquid and non-greasy - belonging to the most sold food additive brand in Brazil (Duas Rodas, 2020) - was obtained from a retailer specialized in the national and international marketing of food additives, located in southeastern Brazil.

The product was stored in an amber bottle, in the amount of $100 \mathrm{~mL}$ and was within the expiration date. Information on the chocolate flavoring label regarding chemical composition was: water, ethyl alcohol, sugar, flavoring substances and caramel IV (INS 150d). On the additive label and on the manufacturer's website, the ratio of $1 \mathrm{~mL}$ flavoring to $1 \mathrm{~L}$ water or to $1 \mathrm{Kg}$ mass was indicated for use. For other Brazilian brands referring to this type of flavoring, the same indication of use was also found.

For this study, the concentration of $100.00 \mu \mathrm{L} / \mathrm{L}$ was initially set for evaluation, a concentration one hundred times lower than that indicated by the manufacturer. Then the concentrations 50.00 and $25.00 \mu \mathrm{L} / \mathrm{L}$ were evaluated. Subsequently, concentrations a thousand times lower than the three initially established were evaluated, which were $1.00 ; 0.50$ and $0.25 \mu \mathrm{L} / \mathrm{L}$. The dilutions were made in distilled water.

We decided to test concentrations lower than those indicated for use by the manufacturer with the intention of approaching the real concentrations absorbed by the human organism. 


\subsection{Cytotoxicity and genotoxicity analysis in Allium cepa root meristems}

Cytotoxicity and genotoxicity of flavoring were assessed on the basis of Fiskesjo (1993). Onion bulbs (variety beta cristal, from an organic garden) were placed in vials with instilled water, constantly aerated, to obtain roots of $2.0 \mathrm{~cm}$ in length. For the analysis of all concentration of flavoring (treatment), an experimental group with five onion bulbs was set up. Before putting the roots in contact with their respective treatments, some roots were collected and fixed to serve as control of the bulb itself, which was identified as time of analysis 0 hour or control of the bulb itself ( $\mathrm{Co}-0$ hour). Then, the other roots were put in their respective treatments for 24 and 48 hours, procedures called exposure times 24 and 48 hours, where roots were collected every 24 hours.

Another five rooted onion bulbs were used as a negative control, where the roots remained in distilled water and were collected at exposure times 0, 24 and 48 hours. A positive control was prepared with methyl methanesulfonate (MMS), a known cytotoxic and genotoxic substance to the $A$. cepa test system, at the concentration $4 \times 10^{-4}$ mol.L-1 , but for this control, roots were collected only at the 24-hour exposure time. All roots collected during the experiment were fixed in 3: 1 Carnoy solution (ethanol: acetic acid) for up to 24 hours, according to Guerra and Souza (2002). For estimates of the mitotic index, cells in interphase, prophase, metaphase, anaphase and telophase were counted to determine the cytotoxic potential. The mitotic index or cell division index was calculated as follows: (Total number of dividing cells/Total number of cells analyzed) x 100. Genotoxic potential was assessed by frequency of cell alterations such as micronuclei, colchicine metaphases, anaphase and telophase bridges, gene amplifications, cells with adhesions, nuclear buds and multipolar anaphases.

The results in A. cepa were analyzed by analysis of variance (ANOVA) and the mean values were compared by the Scott-Knott test with significance set at 0.05 .

\section{Results and discussion}

Based on the results in Table 1, the concentration of $100.00 \mu \mathrm{L} / \mathrm{L}$ of the flavoring caused a decline in cell

Table 1. Mitotic index (\%), cell alteration index (\%) observed in root meristems of $A$. cepa exposed to different concentrations of synthetic chocolate food flavoring, for 24 and 48 hours.

\begin{tabular}{|c|c|c|c|c|}
\hline \multicolumn{5}{|c|}{ Mitotic index (\%) } \\
\hline & & \multicolumn{3}{|c|}{ ET $24 \mathrm{~h}$} \\
\hline \multirow{2}{*}{ PC } & & \multicolumn{3}{|c|}{$3.54 \pm 0.34$} \\
\hline & & $0 \mathrm{~h}$ & ET $24 \mathrm{~h}$ & ET $48 \mathrm{~h}$ \\
\hline \multirow{2}{*}{$\mathrm{NC}$} & & $20.6^{a}$ & $29.8^{a}$ & $21.9^{\mathrm{a}}$ \\
\hline & $\mu \mathrm{L}$ & $0 \mathrm{~h}$ & ET $24 \mathrm{~h}$ & ET $48 \mathrm{~h}$ \\
\hline \multirow{6}{*}{ Chocolate flavoring } & 100.00 & $35.00 \pm 1.72^{a}$ & $7.74 \pm 1.21^{\mathrm{b},}$ & $4.90 \pm 1.10^{\mathrm{b}, *}$ \\
\hline & 50.00 & $24.12 \pm 1.18^{\text {a }}$ & $23.40 \pm 1.20^{\mathrm{a}}$ & $22.42 \pm 1.23^{\mathrm{a}}$ \\
\hline & 25.00 & $25.82 \pm 0.92^{\mathrm{a}}$ & $35.07 \pm 0.89^{a}$ & $30.28 \pm 0.80^{\text {a }}$ \\
\hline & 1.00 & $33.72 \pm 0.90^{\mathrm{a}}$ & $31.98 \pm 1.20^{\mathrm{a}}$ & $35.34 \pm 1.21$ a \\
\hline & 0.50 & $29.80 \pm 2.10^{a}$ & $19.20 \pm 1.82^{\mathrm{a}}$ & $20.46 \pm 2.45^{\mathrm{a}}$ \\
\hline & 0.25 & $35.91 \pm 5.51^{\text {a }}$ & $24.13 \pm 7.84 \mathrm{a}^{\mathrm{a}^{*}}$ & $24.63 \pm 3.02^{\mathrm{a}, *}$ \\
\hline \multicolumn{5}{|c|}{ Cell alteration index (\%) } \\
\hline PC & & & 6.95 & \\
\hline \multirow[t]{5}{*}{$\mathrm{NC}$} & & $0 \mathrm{~h}$ & ET $24 \mathrm{~h}$ & ET $48 \mathrm{~h}$ \\
\hline & & $0.01 \pm 0.42$ & $0.01 \pm 0.59$ & $0.01 \pm 0.55$ \\
\hline & $\mu \mathrm{L}$ & $0 \mathrm{~h}$ & ET $24 \mathrm{~h}$ & ET $48 \mathrm{~h}$ \\
\hline & 100.00 & $0.01 \pm 0.00$ a & $4.17 \pm 1.17^{\mathrm{b},}$ & $7.18 \pm 0.90 \mathrm{~b}, *$ \\
\hline & 50.00 & $0.01 \pm 0.92$ a & $5.06 \pm 0.71 \mathrm{a}, *$ & $7.08 \pm 0.23^{\mathrm{a},{ }^{*}}$ \\
\hline \multirow[t]{4}{*}{ Chocolate flavoring } & 25.00 & $0.01 \pm 1.80^{\mathrm{a}}$ & $3.06 \pm 2.50 \mathrm{a} a$, & $3.15 \pm 2.20 \mathrm{a},{ }^{*}$ \\
\hline & 1.00 & $0.01 \pm 0.60^{\text {a }}$ & $3.04 \pm 0.70 \mathrm{a},{ }^{*}$ & $3.01 \pm 0.55^{\mathrm{a}, *}$ \\
\hline & 0.50 & $0.02 \pm 1.25^{\text {a }}$ & $3.70 \pm 0.98^{\mathrm{b}, *}$ & $3.01 \pm 0.89^{b, *}$ \\
\hline & 0.25 & $0.02 \pm 4.29$ a & $0.09 \pm 2.78^{\mathrm{a}}$ & $0.05 \pm 1.25^{\mathrm{a}}$ \\
\hline
\end{tabular}

h: hour, PC - positive control, NC - negative control, ET - exposure time. Different lower-case letters indicate significant difference in mitotic index or cell alteration index between exposure times, within the same concentration, by analysis of variance (ANOVA) and the mean values were compared by the Scott-Knott test with significance of 0.05. *Similar to mitotic index or cell alteration index of the positive control between exposure times within the same concentration by analysis of variance (ANOVA) and the mean values were compared by the Scott-Knott test with significance of 0.05 . 
division in root tips within 24 hours of exposure, which was significant when compared to its respective control and the mitotic indices of the negative control. In the 48hour analysis time, for this concentration, the reduction in cell division was pronounced in relation to the indices of the control itself, its specific 24-hour analysis time, and the negative control. The cell division index observed in the 48-hour time, for this concentration was similar that obtained for the positive control. Thus, the concentration of $100.00 \mu \mathrm{L} / \mathrm{L}$ chocolate flavoring was cytotoxic to the root meristem cells of $A$. cepa, a condition that intensified with increasing time the roots were exposed to the additive.

Corroborating the result of inhibition of cell proliferation, Silva et al. (2016) evaluated a synthetic, liquid food flavoring of chocolate also produced and marketed in Brazil, in concentrations $0.2 ; 0.4$ and $0.6 \mathrm{~mL} / \mathrm{L}$ - concentrations closer to those usually recommended by manufacturers of chocolate flavor and flavor additives in Brazil, which is $1.00 \mathrm{~mL}$ - and found a drastic reduction in cell proliferation in root meristem tissues of $A$. cepa during 24 and 48 hours of exposure. Likewise, Silva et al. (2017) assessed the toxicity of an artificial, liquid chocolate flavoring marketed in Brazil, in concentrations $0.5 ; 1.0 ; 2.0 ; 5.0$ and $10.0 \mathrm{~mL} / \mathrm{L}$ in bone marrow cells of mice treated via gavage for seven days, and reported a significant cytotoxicity to hematopoietic cells by drastically reducing cell division.

Sales et al. (2017) point out that the severe inhibition of division in normal tissues, such as that observed for concentration $100.00 \mu \mathrm{L} / \mathrm{L}$ chocolate flavoring, and observed by Silva et al. (2017), in their studies, can occur due to the action of agents affecting the integrity of the nuclear spindle during mitosis, promoting significant chromosomal rearrangement. When considering that the principle of the cell cycle is the formation of identical cells, the production of new cells with significant changes in the structure and/or number of chromosomes impedes cell functioning and tends to be eliminated from tissues with normal performance, which can lead to a significant antiproliferative effect.
Unlike the concentration of $100 \mu \mathrm{L} / \mathrm{L}$, concentrations of $50.00 ; 25.00 ; 1.00 ; 0.50$ and $0.25 \mu \mathrm{L} / \mathrm{L}$ flavoring did not interfere with cell proliferation in root meristems, since their mitotic indices were equal to their specific exposure times 24 and 48 hour, as well as to their respective controls and to negative control. However, these concentrations, as well as $100 \mu \mathrm{L} / \mathrm{L}$, in the 24 and 48 hours of exposure, demonstrated a significant number of prophases in detriment to the other phases of mitosis (Figure 1). This condition suggests an aneugenic effect of the chocolate flavoring on plant meristematic tissues. Guedes et al. (2018) report that the occurrence of many cells arrested in prophase signal the presence of chemical agents that slow or stop the mitotic machinery, causing the cell cycle to occur less frequently or, in fact, to stop.

Importantly, for concentrations 100.00; 50.00; 25.00; 1.00 and $0.50 \mu \mathrm{L} / \mathrm{L}$ (Figure 1 ) - in the 24 and 48 hours of exposure to the additive - on average, $85 \%$ cells were in prophase. If cell function does not reverse this situation in times of exposure greater than 48 hours, the number of cells produced will be significantly lower in subsequent cell cycles (Sales et al., 2018). Therefore, in the same way as the significant reduction in the cell division index, this fact when recurrent in a tissue of intense cell proliferation, such as the root meristems used in this study, will not allow cell turnover, which may cause the malfunction of organs and tissues. However, this condition was not observed for the concentration of $0.25 \mu \mathrm{L} / \mathrm{L}$.

Regarding the genotoxic potential, concentrations $100.00 ; 50.00 ; 25.00 ; 1.00$ and $0.5 \mu \mathrm{L} / \mathrm{L}$ of the flavoring (Table 1) induced a significant number of chromosomal and nuclear alterations, with an emphasis on nuclear buds, micronuclei and chromosome breaks, showing once again the potential to cause disturbances in the mitotic apparatus (Figure 2). This condition was no longer observed at a concentration of $0.25 \mu \mathrm{L} / \mathrm{L}$. According to Mendes et al. (2020), nuclear buds tend to form micronuclei due to the elimination of extra genetic material in the main nucleus. This occurs due to chromosomal loss or chromosomal breakage during anaphase and/or telophase, resulting

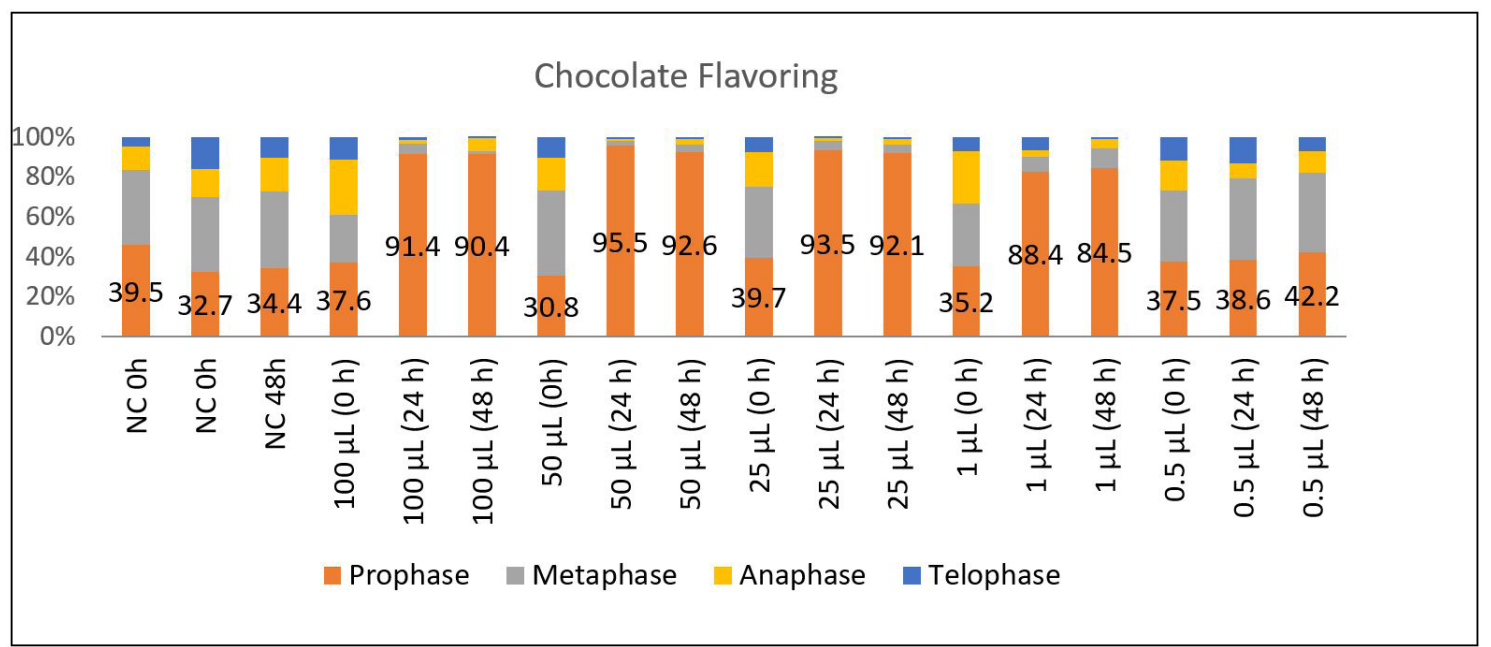

Figure 1. Cell cycle phase indices obtained for the different concentrations of chocolate flavoring at exposure times 0 hour (Co), 24h and 48 hours. Co: Control; NC: Negative Control. 

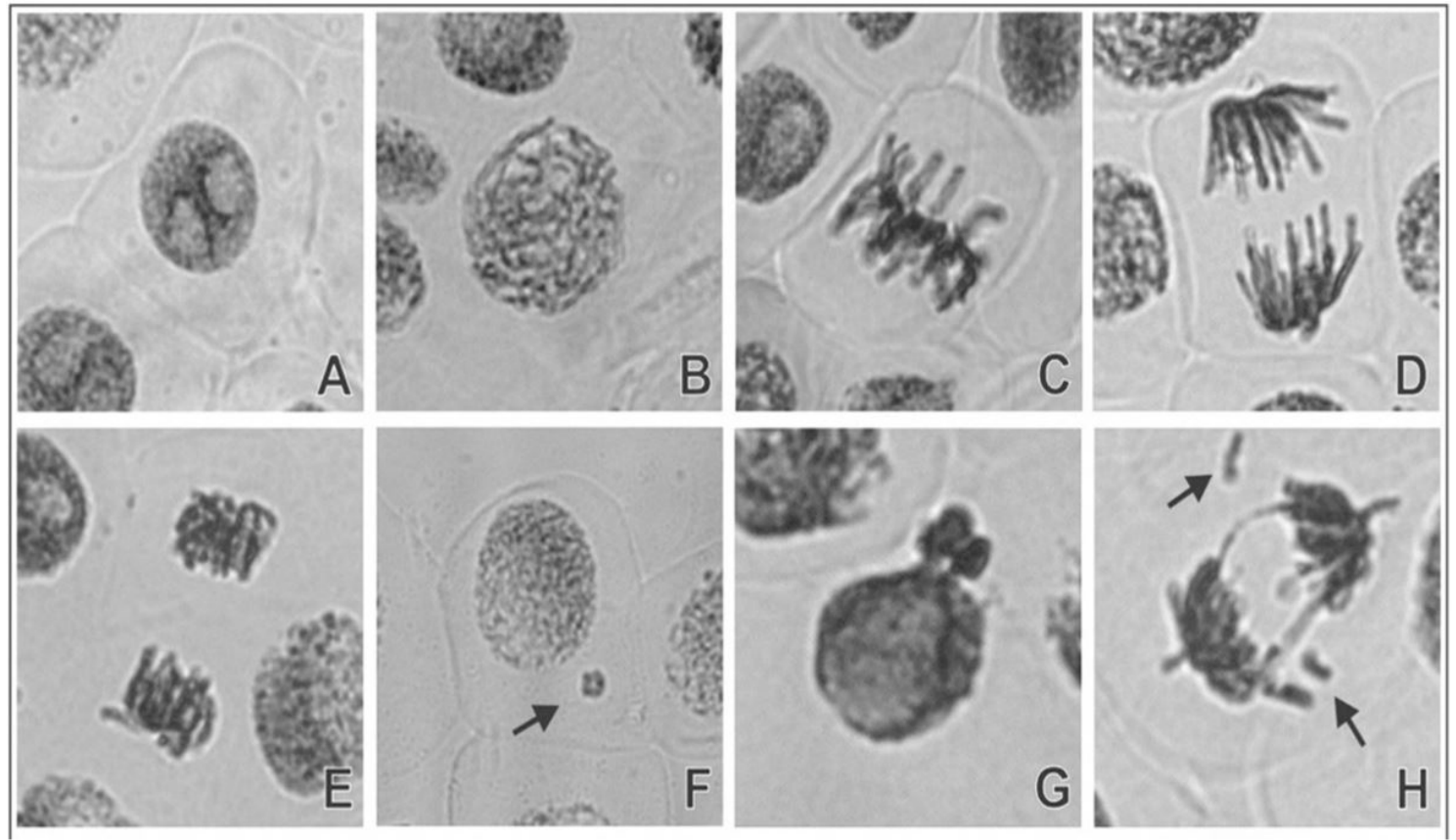

Figure 2. Normal cells and cells with chromosomal and nuclear alterations observed in root meristem cells of $A$. cepa exposed to different concentrations of chocolate flavoring. (A) interphase with two active regions; (B) normal prophase; (C) normal metaphase; (D) normal anaphase; (E) normal telophase; (F) micronucleus (arrow); (G) nuclear nuds, and (H) (arrow) - chromosomal break.

from genotoxic effects induced by clastogenic and/or aneugenic substances. Such alterations in animals, when frequent, are associated with the potentiation or induction of neoplasms and cell death (Queiroz et al., 2013).

As mentioned earlier, benzoic acid and 2,3-butadione diacetyl are the two diluents found in chocolate flavorings. Tested in different concentrations, benzoic acid promoted significant changes in the mitotic spindle, and consequently, in the cell division of human peripheral blood cells cultured in vitro (Demir et al., 2011). In the same way, diacetyl caused a significant damage to chromosome 11-specific loci of chronically and orally treated rodents, causing loss of expression of genes essential to cell division, and interrupting the cell cycle in the bone marrow of these animals (Whittaker et al., 2008). More et al. (2012) reported that the diacetyl diluent had the potential to replace thymine with guanine in euchromatic regions of chromosomes responsible for the cell division of different tissues in rats, in addition to causing the breakdown of hydrogen and disulfide bonds in the tertiary structure of enzymes important for mitosis.

Furthermore, potassium citrate, a preservative commonly used in aroma and flavor chocolate additives, caused, in concentrations above $100.00 \mu \mathrm{L} / \mathrm{L}$, cytotoxicity to A. cepa root meristems, significantly inhibiting the cell division (Türko lu, 2007). Flavor enhancers, potassium glutamate and magnesium diglutamate, also present in aroma and flavor chocolate additives, demonstrated cytotoxic, aneugenic and genotoxic potential in human lymphocyte culture. Still, ethyl vanilla flavor enhancer had the potential to break hydrogen bonds between adenine and thymine bases in the minor groove of DNA molecules
(ctDNA) of calf thymus, demonstrating the ability to alter the transcriptional process of these regions (Xia et al., 2017).

It is important to emphasize that the concentrations evaluated in this study are much lower than those used commercially. Even though they were smaller, cytotoxicity was observed, as for the $100 \mathrm{uL}$ concentration. Also, for concentrations below 100 uL genotoxicity was observed. However, unlike other studies found in the scientific literature evaluating chocolate flavoring, in the present manuscript it was possible to determine from which concentration the additive does not cause cytotoxicity and genotoxicity, 50 and $25 \mathrm{uL}$, respectively.

The results obtained here added to those in the literature on the cellular level toxicity of this type of flavoring, as well as the chemical compounds present in its formulation, are subsidies for food security agencies to regulate its use and provide safety to the consumer population.

\section{References}

BRASIL. Ministério da Saúde. Agência Nacional de Vigilância Sanitária, 2007 [viewed 9 July 2020]. Resolução RDC n.2, de 15 de janeiro de 2007. Aprova a "Resolução da Diretoria Colegiada que aprova o regulamento técnico sobre aditivos aromatizantes, que consta como anexo da presente Resolução" [online]. Diário Oficial da República Federativa do Brasil, Brasilia. Available from: http:// www.anvisa.gov.br/legis/resol/2007/rdc/02_170107rdc.htm

CARITÁ, R. and MARIN-MORALES, M.A., 2008. Induction of chromosome aberrations in the Allium cepa test system caused by the exposure of seeds to industrial effluents contaminated with azo dyes. Chemosphere, vol. 72, no. 5, pp. 722-725. http:// dx.doi.org/10.1016/j.chemosphere.2008.03.056. PMid:18495201. 
DEMIR, E., KOCAGLU, S. and KAYA, R. (2011). Assessment genotoxic effects of benzyl derivatives by comet assay. Food and Chemical Toxicology, vol. 48, no. 5, pp. 1239-1242. https://doi.org/10.1016/j. fct.2010.02.016.

DUAS RODAS, 2020 [viewed 13 April 2006]. Flavors. Available from: https://www.duasrodas.com/produtos/flavors/condimentose-aditivos/

FISKESJÖ, G., 1993. The Allium test in wastewater monitoring. Environmental Toxicology and Water Quality, vol. 8, no. 3, pp. 291-298. http://dx.doi.org/10.1002/tox.2530080306.

GUEDES, C.M., SANTOS, F.K.S., SILVA, T., SILVA, A.P.S., LIMA, M.V.S., OLIVEIRA, V.A., SILVA, M.E.S., ABREU, M.C. and PERON, A.P.P., 2018. Cytotoxic and genotoxic potential of Ginkgo biloba L., in industrialized and without-additive forms. Bioscience Journal, vol. 34, no. 4, pp. 1017-1024. http://dx.doi.org/10.14393/BJv34n1a2018-39745.

GUERRA, M. and SOUZA, M.J. (2002). Como observar os cromossomos: um guia de técnicas em citogenética vegetal, animal e humana. Ribeirão Preto: FUNPEC, 300 p.

HERRERO, O., MARTÍN, J.P., FREIRE, O.F., LÓPEZ, L.C., PEROPADRE, A. and HAZEN, M.J. (2012). Toxicological evaluation of three contaminant of emerging concern by use of Allium cepa test. Mutation Research, vol. 743, no. 1-2, pp. 24-34. https://10.1016/j. mrgentox.2011.12.028.

KOCA, N., ERBAY, Z. and KAYMAK-ERTEKIN, F., 2015. Effects of spray-driping conditions on the chemical, physical and sensory properties of cheese powder. Journal of Dairy Science, vol. 98, no. 5, pp. 2934-2943. http://dx.doi.org/10.3168/jds.2014-9111.

MARQUES, G.S., SILVA, S.I.O., SOUSA, J.M.C., FERREIRA, P.M.P. and PERON, A.P., 2015. Cytotoxic and genotoxic potential of liquid synthetic food flavorings evaluated alone and in combination. Food Science and Technology (Campinas), vol. 35, no. 1, pp. 183188. http://dx.doi.org/10.1590/1678-457X.6596.

MENDES, S.A., GONÇALVES, É.V., FRÂNCICA, L.S., CORREIA, L.B.C., NICOLA, J.V.N., PESTANA, A.C.Z., DA SILVA MEDEIROS, F.V., DE SOUZA, W.E., INEU, R.P. and PERON, A.P., 2020. Quality of natural waters surrounding Campo Mourão, State of Paraná, Southern Brazil: water resources under the influences from urban and agricultural activities. Water, Air, and Soil Pollution, vol. 231, no. 8, pp. 1-10. http://dx.doi.org/10.1007/s11270-020-04795-5.

MORE, S.S., RAZA, A. and VINCE, R. (2012). The butter flavorant, diacetyl, forms a covalent adduct with 2-deoxyguanosine, uncoils DNA, and leads to cell death.Journal of Agricultural and Food Chemistry, vol. 60, no. 12, pp. 3311-3317. http://dx.doi. org/10.1021/jf300180e.

QUEIROZ, F.M.D., MATIAS, K.W.D.O., CUNHA, M.M.F.D. and SCHWARZ, A., 2013. Evaluation of (anti) genotoxic activities of Phyllanthus niruri L. in rat bone marrow using the micronucleus test. Brazilian Journal of Pharmaceutical Sciences, vol. 49, no. 1, pp. 135-148. http://dx.doi.org/10.1590/S1984-82502013000100015.

RAMESH, M. and MUTHURAMAN, A. (2018). Flavoring and coloring agents: health risks and potential problems. In: A.M. GRUMEZESCU and A.M. HOLBAN, eds. Natural and artificial flavoring agents and food dyes. London: Academic Press, pp. 1-28. http://dx.doi.org/10.1016/B978-0-12-811518-3.00001-6.
ROCHA, R.B.R., PERON, A.P.P., SANTOS, F.K.S.S., MARQUES, M.M.M.M., SOUSA, M.E.S.S., OLIVEIRA, V.A.D.O. and NASCIMENTO, A.L.D.N., 2018. Toxic, cytotoxic and genotoxic potential of synthetic food flavoring. Acta Toxicológica Argentina, vol. 26, no. 2, pp. 65-70.

SALES, I.M.S., SANTOS, F.K.S., SOUSA, J.M.C., SILVA, F.C.C., \& PERON, A.P., 2017. Acute toxicity of grape, plum and orange synthetic food flavourings evaluated in vivo test systems. Food Technology and Biotechnology, vol. 55, no. 1, pp. 131-137.

SALES, I.M.S., SILVA, J.M., MOURA, E.S.R., ALVES, F.D.S., SILVA, F.C.C., SOUSA, J.M.C. and PERON, A.P., 2018. Toxicity of synthetic flavorings, nature identical and artificial, to hematopoietic tissue cells of rodents. Brazilian Journal of Biology = Revista Brasileira de Biologia, vol. 78, no. 2, pp. 306-310. http://dx.doi. org/10.1590/1519-6984.07716.

SANTOS, F.K.D.S., MARQUES, M.M.M., VAN TILBULRG, M.F., GUEDES, M.I.F., BUENO, P.A.A. and PERON, A.P., 2020. Toxicity of food flavorings to ex-vivo, in vitro and in vivo bioassays. Acta Scientiarum. Technology, vol. 42, no. 2, pp. 44867.

SHERWOOD, C.L. and BOITANO, S., 2016. Airway epithelial cell exposure to distinct e-cigarette liquid flavorings reveals toxicity thresholds and activation of CFTR by the chocolate flavoring 2 , 5-dimethypyrazine. Respiratory Research, vol. 17, no. 1, pp. 57. http://dx.doi.org/10.1186/s12931-016-0369-9. PMid:27184162.

SILVA, E.L., SALES, I.M.S., SANTOS, F.K.S. and PERON, A.P., 2017. Processed fruit juice ready to drink: screening acute toxicity at the cellular level. Acta Scientiarum. Biological Sciences, vol. 39, no. 2, pp. 195-200. http://dx.doi.org/10.4025/actascibiolsci. v39i2.33699.

SILVA, S.I.O., SANTANA, G.M., SALES, I.M.S., SOUSA, J.M.C. and PERON, A.P., 2016. Toxicity in food flavorings at the cellular level associated with each other at different doses. Acta Scientiarum. Biological Sciences, vol. 38, no. 1, pp. 77-84. http:// dx.doi.org/10.4025/actascibiolsci.v38i1.30475.

SILVA, T.S., SILVA, A.P.S., DE ALMEIDA SANTOS, A., RIBEIRO, K.G., SOUZA, D.C., BUENO, P.A.A., MARQUES, M.M.M., ALMEIDA, P.M. and PERON, A.P., 2020. Cytotoxicity, genotoxicity, and toxicity of plant biostimulants produced in brazil: subsidies for determining environmental risk to non-target species. Water, Air, and Soil Pollution, vol. 231, no. 3, pp. 233. http:// dx.doi.org/10.1007/s11270-020-04614-x.

TABREZ, S. and AHMAD, M., 2011. Components of antioxidative system in Allium cepa as the toxicity monitor of trichloroethylene (TCE). Toxicological and Environmental Chemistry, vol. 93, no. 1, pp. 73-84. http://dx.doi.org/10.1080/02772248.2010.498375.

TÜRKO LU, ., 2007. Genotoxicity of five food preservatives tested on root tips of Allium cepa L. Mutation Research, vol. 626, no. 1-2, pp. 4-14. http://dx.doi.org/10.1016/j.mrgentox.2006.07.006.

WHITTAKER, P., CLARKE, J., SAN, R.H., BEGLEY, T.H. and DUNKEL, V.C. (2008). Evaluation of the butter flavoring chemical diacetyl and a fluorochemical paper additive for mutagenicity and toxicity using the mammalian cell gene mutation assay in L5178Y mouse lymphoma cells. Food and Chemical Toxicology, vol. 46, no. 8, pp. 2928-2933. http://dx.doi.org/10.1016/j.fct.2008.06.001.

XIA, K., ZHANG, G., LI, S. and GONG, D., 2017. Groove binding of vanillin and ethyl vanillin to calf Thymus DNA. Journal of Fluorescence, vol. 27, no. 5, pp. 1815-1828. http://dx.doi. org/10.1007/s10895-017-2119-X. 